Author's draft 10/27/2010

Published at: 20 Current Directions in Psychological Science 58-62 (2011)

DOI: $10.1177 / 0963721410397283$

published version available at: http://cdp.sagepub.com/content/20/1/58

\title{
The Psychology of Trial Judging
}

Neil Vidmar, Duke University School of Law and Professor of Psychology, Duke University

\begin{abstract}
Trial court judges play a crucial role in the administration of justice for both criminal and civil matters. Although psychologists have studied juries for many decades they have given relatively little attention to judges. Recent writings, however, suggest increasing interest in the psychology of judicial decision making. This essay reviews several selected topics where judicial discretion appears to be influenced by psychological dispositions, but cautions that a mature psychology of judging field will need to consider the influence of the bureaucratic court setting in which judges are embedded, their legal training, and the constraints of legal precedent.
\end{abstract}

Trial judges are on the front line of civil and criminal disputes. At early stages of litigation they make rulings about relevant law bearing on the dispute: e.g., about whether a plea bargain is acceptable; about who has standing to sue; whether the court has jurisdiction; whether the litigation is "ripe" for further attention by the court; whether the claims have merit; or whether a statute of limitations is or is not applicable. Trial judges also manage settlement conferences, approve plea bargains and preside over jury trials. Often they serve as the primary fact finder instead of a jury. Trial judges also render 
sentences in criminal cases and review civil jury verdicts, including adjusting damage awards through remittitur or additur.

These various decision making activities are potentially subject to influence by the judge's personality, attitudes, past experiences or other factors that have been shown to operate in other areas of human behavior. While a recent book discussing the psychology of judicial decision making indicates increasing interest in the subject (Klein and Mitchell, 2010), to date the existing body of empirical research on trial judges is very small. In this essay I review several selected topics with the goal of engendering broader interest in trial judge decision making.

First, however, I draw attention to the fact that a mature field of the psychology of judging must take into consideration some unique considerations, namely (a) the training and experience that ostensibly make judges different than laypersons and (b) legal and organizational constraints on judicial behavior.

\section{Legal Training, Legal Precedent and Role Constraints}

In their professional training lawyers are taught to look at facts and to reason by analogy, applying facts by placing them in categories, just as is true in scientific disciplines. However, as Schauer (2008) has cogently written, legal decision making also requires heavy deference to precedent. The judge's role formally requires an understanding that personal beliefs about the most just outcome of a particular dispute must often be subjugated in deference to consistency with the relevant body of law. ${ }^{1}$

\footnotetext{
${ }^{1}$ Among a number of examples, Schauer drew attention to Supreme Court Justice Potter Stewart's dissent in Griswold v, Connecticut, the 1965 case involving the right to purchase contraceptives. While the majority opinion articulated a right to privacy as the basis for allowing the purchase of contraceptives, Stewart dissented, arguing that there was no right to privacy mentioned in the Constitution. However, in the subsequent case of Roe.v. Wade in 1973, also invoking a right to privacy, he voted with the majority because Griswold had set a precedent, namely that there was now a right to privacy. Trial judges too are
} 
Judges know that if they deviate too far from prior case law or statutory guidelines their ruling will be appealed—and likely overturned by an appellate court. In short, precedent and statutory requirements often constrain psychological dispositions.

A second problem is that, unlike continental European systems that allow the judge investigative powers, under the American adversary system the judge is primarily dependent on the evidence provided by the litigating parties (see, e.g. Damaska, 1986). If one or both of the opposing parties present deficient or incomplete evidence the quality of the judge’s decision will be affected.

A third problem is that much of the daily work of the trial judge is embedded in the court's bureaucracy. Cases are decided in chambers and in written orders (see, e.g., Levi and Gulati, 2008). In consequence, many judicial decisions are made in a context that imposes major constraints on investigating how those decisions are made.

I will return to these issues at the end of the essay.

\section{Does Legal Training and Experience Insulate Judges}

\section{From Common Cognitive Errors?}

In a seminal study Landsman and Rakos (1994) created an experiment involving judges and laypersons who were asked to decide a hypothetical products liability case. In one condition the participants in the study learned facts that could not legally be considered; in another they learned those facts with an instruction that the information was inadmissible and should be disregarded; a control condition did not contain the inadmissible information. Compared to the control condition, the inadmissible information had a negative impact on both judge and juror decisions. Strikingly, the

bound by precedents in case law, by statutes, or by other constraints such as rules of evidence or sentencing guidelines. 
instruction that the evidence was inadmissible failed to have an effect on judges as well as jurors, suggesting that legal training did not inoculate judges from ordinary human error.

Wistrich, Guthrie and Rachlinski (2005) conducted a series of experiments similar to the Landsman and Rakos study. Their experiments included cases involving a plaintiff with prior criminal convictions; conversations protected by attorney-client privilege; the sexual history of an alleged rape victim; prior demands disclosed during a settlement conference; and a government promise not to rely on certain background information during a sentencing hearing. The researchers found that judges were unable to disregard inadmissible evidence, although with important exceptions. When faced with a fact pattern involving an inadmissible search or an inadmissible confession the judges were able to put that information aside. In still another set of experiments in their program Rachlinski et al. (2009) found that on an "implicit associations test" judges were as prone as other persons to exhibit stereotypes of Black Americans; and in a series of vignettes that subtly primed racial issues the judges were prone to impose harsher penalties on Black defendants than on White defendants. However, in a vignette where the defendant’s race was made explicit White judges did not show bias against Black defendants (albeit Black judges in the experiment were significantly more prone to convict a White defendant than a Black defendant).

What can we make of these findings? One interpretation is that despite their legal training judges are no different than laypersons in being prone to cognitive biases. On the other hand, the lack of real world context in simulation experiments may artificially inflate the effects of biases. In actual trials judges weigh inadmissible evidence along 
with many other pieces of evidence, including arguments by opposing legal counsel, so any effects of implicit biases may be nugatory. The Rachlinski et al. study hints that when judges have more detailed information and more time to consider and deliberate, their training allows them to process information differently than laypersons. However, research on sentencing decisions implicating race gives reason to pause.

\section{Sentencing Decisions: Deviations from the Ideal Norm}

Mustard (2001) obtained a sample of 77,235 offenders sentenced under the federal Sentencing Reform Act of 1984. The Act's purpose was to reduce sentence disparity between races, ethnic backgrounds and gender. The Act, however, permits judges to deviate from the guidelines by considering specific aggravating or mitigating circumstances. After controlling for a large number of variables associated with the cases, Mustard found differences associated with race, ethnicity and gender. The disparities were associated primarily with downward departures from the guidelines rather than differential sentencing within the prescribed ranges. Whites received an average sentence of 32.1 months, Hispanics received an average sentence of 54.1 months, and African Americans an average of 64.1 months. Being African American accounted for about fifty-five percent of the variance. Black defendants were less likely to receive a downward departure from the guidelines and more likely to receive an upward adjustment. $^{2}$

The potential effects of race on sentencing may be subtle and invidious. Blair, Judd and Chapleau (2004) obtained a random sample of 100 Black and 116 White

\footnotetext{
${ }^{2}$ Yet, the data also showed that Blacks and males were also less likely to receive no prison term when that option was available. The type of crime also affected the length of sentence. For example, persons convicted of drug trafficking and firearm possession associated with drug trafficking were more likely to receive harsher sentences. The Mustard findings show complexity in the sentencing behavior of judges that requires additional investigation.
} 
inmates incarcerated in the Florida Department of Corrections. Blair et al. coded the seriousness of the defendants' primary offense but also took into consideration prior offenses. Photographs of each of the incarcerated persons were obtained and rated on the degree to which each convict had features typical of African Americans as well as some other potentially confounding features like "attractiveness." Seriousness of the crime accounted for the majority of the variance and race of the offender accounted for only an insignificant percentage of the variance. However, the striking finding involved the variance within the African American sample. African Americans who were rated as having the most Afrocentric features had received significantly longer sentences even after other factors were controlled in the equations. This intriguing finding is generally consistent with other research (e.g. Eberhardt et al., 2006) indicating that physical appearance affects sentencing decisions. The Blair et al. research suggests that there may be human error effects that are difficult to eradicate even with sentencing guidelines.

But are there alternative explanations for the Blair et al. results? A largely unstudied issue has been the effects of the defendant's demeanor and language in the courtroom. Many African Americans and other minorities have distinctive demeanors and ways of speaking that could influence the decisions of judges. Speech styles and demeanors of African American defendants, compared to White defendants, might provide a partial explanation of the differential sentencing patterns. As noted earlier, judges depend on others to provide the facts on which they make their decisions. Might some of the bias be attributed to probation officers who prepare pre-sentencing reports for the judges? Could the chain of causality be traced even further back? Bail conditions imply degrees of dangerousness or likelihood of flight and some research has indicated 
that magistrates, who determine bail conditions at the time of arrest, were more inclined to require monetary bail for Blacks compared to Whites, and set the amounts at higher levels. Do Blacks have poorer legal representation than Whites? In short, while we should not eliminate implicit racial biases in judicial sentencing, other plausible causes need to be considered.

\section{Intellectual, Attitudinal and Political and Context Effects On Judicial Gate Keeping Decisions}

One gate-keeping role of the judge is to decide whether scientific or other evidence espoused by a proffered expert meets sufficient standards of reliability to be admitted as evidence. In Daubert v. Merrell Dow Pharmaceuticals (1993) and subsequent cases, the Supreme Court enunciated criteria the judge should use to make decisions on admissibility: (a)the theory or technique must be falsifiable and testable; (b)the research has been subjected to peer review (c) the known or potential error rate; and (d)the degree of acceptance in the scientific community. Admissibility of expert testimony raises interesting issues.

Gatowski et al. (2001) surveyed a sample of 400 state court trial judges. Although the judges overwhelmingly supported the idea of Daubert standards, the survey revealed that only five percent of the judges could articulate the meaning of the "falsifiability" criterion and only four percent demonstrated a clear understanding of error rate.

Kovera and McAuliff (2000) conducted an experiment with a sample of 380 Florida circuit court judges, who were provided a general description of expert testimony bearing on sexual harassment and asked the judges to decide on its admissibility. There 
were several experimental conditions affecting the validity of the testimony. The judges' decisions to admit or exclude the evidence were not sensitive to factors that confounded internal validity (see also, Groscup, 2004).

Empirical researchers from the field of political science have long asked if political leanings affect the gate-keeping decisions of appellate court. Rowland and Todd (1991) asked a similar question about federal trial court judges by comparing gatekeeping decisions made by judges appointed during the Nixon/Ford, Carter and Regan administrations. There were no major overall differences between the respective presidential appointees in terms of permitting or denying parties standing to sue, but the data also showed that there were differences in who was granted and who was denied standing. Carter judicial appointees were more likely to grant standing to "underdog” plaintiffs such as unions, employees, minorities, aliens, individuals and criminals. In contrast Regan and Nixon appointees tended to favor "upperdog” plaintiffs such as corporations and governmental litigants. Kulik, Perry and Pepper (2003) found no effects of judges' gender or race, in sexual harassment litigation, but judges appointed by Democrat presidents were more likely to decide in favor of plaintiffs. Thus, political leanings appear to have affected judges’ gate keeping activities.

Guthrie, Rachlinski and Wistrich (2001) conducted an experiment in which judges were asked to award damages in a personal injury suit in a federal court. Personal injury cases are allowed in federal court if they exceed $\$ 75,000$. Half of the judges were first asked to rule on a defense challenge that the damages in the case did not meet the $\$ 75,000$ minimum limit; the limit issue was not raised for the control condition judges. Most of the judges asked to decide whether the case could proceed in federal court ruled 
that it could, but in comparison to the control judges, their compensatory awards were significantly lower. Guthrie et al. concluded that deciding the dispute over whether the damages met the minimum limit for federal court served as a psychological anchor inclining the judges toward lower awards.

\section{Judicial Concerns with Distributive versus Procedural Justice}

Over the past several decades much attention has been given to the topic of procedural justice in a wide range of settings (see Tyler, 2006). Literally hundreds of studies have shown that people's perceptions of whether they have been treated fairly matter a great deal, sometimes more than the actual outcome of a dispute. Heuer, Penrod and Kattan (2007) conducted two experiments, the first with 70 state appellate judges and the second with 75 trial court judges, that assessed the degree to which judges focused on procedural justice. The judges were sent a questionnaire containing a hypothetical scenario involving an airline passenger who was stopped, questioned and had his luggage searched. Four versions of the scenario involved respectful versus very disrespectful treatment by the security officers crossed with information on whether the luggage contained a weapon or marijuana (high benefit versus low benefit of the search). The person was subsequently arrested and convicted in all four scenarios. The judges were asked to decide whether the conviction should be upheld plus a number of other questions about the fairness of the procedures under which the arrest took place. The only variables that uniquely affected the judges’ decisions were whether the search yielded a weapon (high benefit) or marijuana (low benefit) and the degree to which the treatment infringed upon the airline passenger's freedom. The important implication of the Heuer et al. study is that judges apparently used different criteria than those typically discussed in the 
procedural justice literature. The experiment raises many interesting and important questions requiring further research.

\section{Judges as Alternatives to Juries}

Beginning with Kalven and Zeisel’s classic empirical work on the American jury system a number of studies have used the opinions or decisions of judges as a standard to compare the performance of juries. The various studies continuously find that judges and juries have an approximately 80 percent agreement rate regarding the proper verdict in both criminal and civil trials. In the 20 percent of criminal cases where there is disagreement the judges are more inclined to convict than the jury. Among several likely explanations for the disagreement is the fact that the judges often have more information about the defendant's prior criminal record (not usually disclosed to the jury) and other knowledge and experience that causes them to side with the prosecution's evidence. It is also possible that judges have a different interpretation of "proof beyond a reasonable doubt” than layperson jurors.

While juries decide the bulk of damage awards in civil trials, sometimes judges fulfill this role. Wissler, Hart and Saks (1999) investigated how samples of judges, lawyers who primarily defended civil cases and laypersons decided compensatory damages. The awards made by the laypersons were generally higher and more variable than those made by the judges. Laypersons also tended to see the injuries as more severe. However, judges were generally similar to laypersons in their assessments of the characteristics of the injuries.

\section{Future Research Topics}


While research on judges' susceptibility to common cognitive errors is important, more data are needed to determine the influence they have in the context of a real trial or hearing which typically involves many pieces of evidence plus arguments from lawyers on both sides about the meaning of that evidence and its relevance under legal precedents. My proposed alternative explanations for racial discrimination in sentencing would suggest the need for systematic qualitative work to complement archival and experimental research in order to understand judicial behavior. Psychologists have been hesitant to engage in qualitative research, but qualitative research has an especially important role to play in a mature field of the psychology of judging.

The number of persons who file and pursue or defend their legal claims without a lawyer has been growing and pro se litigants have become a major topic of discussion in both federal and state courts (see, Landsman, 2009). There has been concern that some judges deal with these litigants in a cursory manner because the litigants often do not know the legal rules and procedural steps that courts require. To what extent do judges make exceptions for these litigants and to what degree do they focus only on substantive justice outcomes versus providing litigants with a sense of procedural justice? The Heuer et al. (2007) study, discussed above, indicated that judges appeared to be more influenced by outcome than by procedural justice concerns. To what degree might such factors affect both distributive and procedural outcomes in pro se litigation?

Finally, Schauer's (2008) critique of the psychological literature assuming that legal reasoning is primarily reasoning only by analogy raises very basic and interesting scientific questions. As he pointed out, there exists no clear articulation of a theory of judicial psychology taking into account the critical role of precedent in legal decisions. 
Moreover, issues of precedent apply to many areas beyond the legal context, such as organizational decisions. A substantial effort to explore the effects of precedent in judicial decision making could open a much broader field of inquiry.

\section{Recommended Reading}

David Klein and Gregory Mitchell (2010). The Psychology of Judicial Decision Making, Oxford University Press.

Edward Levi (1949). An Introduction to Legal Reasoning, Chicago: University of Chicago Press.

Frederick Schauer, Why Precedent in Law (and Elsewhere) is Not Totally (or Even Substantially) About Analogy (2008) Perspectives on Psychological Science 3: 454-460

\section{References}

Blair, I.V., Judd, C.M., \& Chapleau, K.M. (2004). The influence of Afrocentric facial features in criminal sentencing. Psychological Science, 15, 674-679.

Damaska, M. (1986), The Faces of Justice and State Authority: A Comparative Approach to the Legal Process. New Haven, CT:Yale University Press.

Eberhardt, J.L., Davies, P.G., Purdie-Vaughns, V.J., \& Johnson, S.L. (2006). Looking deathworthy: perceived stereotypicality of black defendants predicts capital-sentencing outcomes. Psychological Science, 17. 383 - 386.

Gatowski, S.I., Dobbin, S.A., Richardson, J.T., Ginsburg, G.P., Merlino, M.L., \& Dahir, V. (2001). Asking the gatekeepers: A national survey of judges on judging expert evidence in a post-Daubert world. Law and Human Behavior, 25, 433-458.

Groscup, J.L. (2004). Judicial decision making about expert testimony in the aftermath of Daubert and Kumho. Journal of Forensic Psychology Practice, 4, 57-66.

Guthrie, C., Rachlinski, J.J., \& Wistrich, A.J. (2001). Inside the judicial mind. Cornell Law Review, 86, 777-830.

Heuer, L., Penrod, S., \& Kattan, A. (2007). The role of societal benefits and fairness concerns among decision-makers and decision recipients. Law \& Human Behavior, 31, 573-610. 
Klein, D.E. \& Mitchell, G. (2010). Klein, D.E. \& Mitchell, G. (2010). The psychology of judicial decision making. New York, NY: Oxford University Press. New York, NY:

Oxford University Press.

Kovera, M.B., \& McAuliff, B.D. (2000). The effects of peer review and evidence quality on judge evaluations of psychological evidence: Are judges effective gatekeepers? Journal of Applied Psychology, 85, 574-586.

Kulik, C.T., Perry, E.L., \& Pepper, M.B. (2003). Here comes the judge: The influence of judge personal characteristics on federal sexual harassment case outcomes. Law and Human Behavior, 27, 69-97.

Landsman, S. (2009). The Growing Challenge of Pro Se Litigation. Lewis \& Clark Law Review, 13, 439-460.

Landsman, S., \& Rakos, R.F. (1994). A preliminary inquiry into the effect of potentially biasing information on judges and jurors in civil litigation. Behavioral Sciences and the Law, 12, 113-126.

Levi, D.F. \& Gulati, G.M. (2008). Judging measures. University of Missouri-Kansas City Law Review, 77, 381-413.

Mustard, D.B. (2001). Racial, ethnic, and gender disparities in sentencing: Evidence from the U.S. federal courts. Journal of Law and Economics, 44, 285-314.

Rachlinski, J., Johnson,S., Wistrich, A., and Guthrie,C. Does Unconscious Racial Bias Affect Trial Judges?, Notre Dame Law Review , 84, 1195-1246.

Rowland, C.K., \& Todd, B.J. (1991). Where you stand depends on who sits: Platform promises and judicial gatekeeping in the federal district courts. Journal of Politics, 53, 175-185.

Schauer, F. (2008). Why precedent in law (and elsewhere) is not totally (or even substantially) about analogy, Perspectives on Psychological Science, 3, 454-460.

Schauer, F. (2010) Is there a Psychology of Judging? In Klein, D.E. \& Mitchell, G.,eds. The Psychology of Judicial Decision Making,103-120. New York, NY: Oxford University Press.

Simon, R., \& Mahan, L. (1971). Quantifying burdens of proof: A view from the bench, the jury, and the classroom. Law and Society Review, 5, 319-330.

Tyler, T.R. (2006). Why people obey the law: Procedural justice, legitimacy, and compliance. Princeton: Princeton University Press. 
Wissler, R.L., Hart, A.J., Saks, M.J. (1999). Decisionmaking about general damages: A comparison of jurors, judges, and lawyers. Michigan Law Review, 98, 751-826.

Wistrich, A.J., Guthrie, C., \& Rachlinski, J.J. (2005). Can judges ignore inadmissible information? The difficulty of deliberately disregarding. University of Pennsylvania Law Review, 153, 1251-1345. 